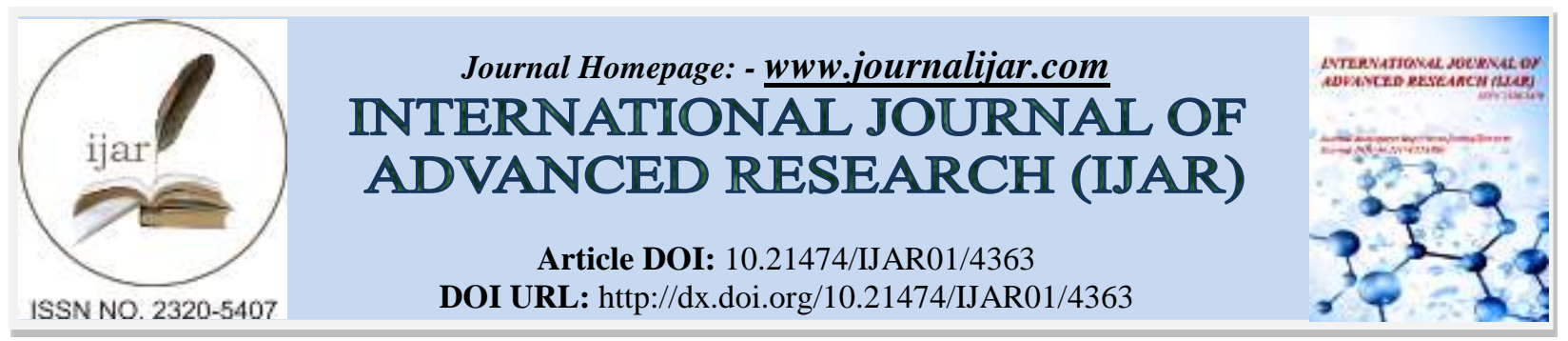

RESEARCH ARTICLE

\title{
STUDY OF SERUM PROTEIN ELECTROPHORESIS IN ELDERLY INDIVIDUALS \& ITS CO- RELATION WITH REGARD TO OTHER PARAMETERS.
}

1. Tutor, AIIMS, Patna.

\author{
Nishi $^{1}$, Talat Fatma ${ }^{2}$ and Ajit Kumar Chaudhary ${ }^{3}$.
}

2. Assistant Professor, Darbhanga Medical College, Laheriasarai, Darbhanga.

3. Professor and Head of Department, Darbhanga Medical College, Laheriasarai, Darbhanga.

\section{Manuscript Info}

\section{Manuscript History}

Received: 26 March 2017

Final Accepted: 30 April 2017

Published: May 2017

\section{Key words:-}

Prevalence, Serum protein electrophoresis, monoclonal gammopathy of undetermined significance, Elderly.

\section{Abstract}

Introduction: Serum protein electrophoresis is used to identify patients with Monoclonal gammopathy including multiple myeloma, Monoclonal gammopathy of undetermined significance (MGUS), polyclonal gammopathies and other related disorders. Electrophoresis separates proteins based on their physical properties, and the subsets of these proteins are used in interpreting the results. Monoclonal gammopathies are associated with a clonal process that is malignant or potentially malignant. The quantity of $M$ protein, the results of bone marrow biopsy, and other characteristics helps in differentiating multiple myeloma from the other causes of monoclonal gammopathy including MGUS.

Aim and objective : The aim of this study was (i) to evaluate the elderly individuals (age >50 years) with abnormal serum protein electrophoresis pattern, (ii) to differentiate the various conditions of abnormal serum protein electrophoresis, (iii) to identify and differentiate the cases of monoclonal gammopathies, (iv) to evaluate the prevalence of monoclonal gammopathy of undetermined significance (MGUS) in our part of country \& (v) to correlate serum protein electrophoresis pattern with other parameters specially liver function tests and kidney function tests.

Materials and methods: This prospective study was carried out in the Department of Pathology, Darbhanga Medical College and Hospital, Laheriasarai. Total 200 elderly individuals of age more than 50 years comprising of equal number of males (100) and females (100) were included in this study. Following proper detailed history and physical examination, venous blood sample was collected with proper aseptic care and serum is obtained after centrifugation. Each serum sample was subjected to total protein estimation and Serum protein electrophoresis. Patients were further evaluated for other parameters e.g., complete blood count (CBC), liver function test, kidney function test, hematological tests and others.

Results: Out of 200 cases 28 (14\%) cases had abnormal serum protein electrophoresis pattern, of which $3(1.5 \%)$ cases had Monoclonal Gammopathy, 20 (10\%) cases had Polyclonal Gammopathy and 2.5\% 
cases had Hypoalbunemia. Among Monoclonal Gammopathy, 2 (1\%) cases were of Monoclonal Gammopathy of Undetermined Significance (MGUS) and only one $(0.5 \%)$ case was of Multiple Myeloma. All 3 cases of Monoclonal gammopathy were of age $>60$ years. The mean age of the individuals in this study group was 62.83 years. The mean age of cases of Monoclonal gammopathy was this study was 69.66 years.

Conclusion: In conclusion, Prevalence of Monoclonal Gammopathy, Monoclonal Gammopathy of Undetermined Significance (MGUS) and that of Multiple Myeloma (MM) in our part of the country i.e. North Bihar are $1.5 \%, 1 \%$, and $0.5 \%$ respectively. Prevalence of Multiple Myeloma (MM) and that of Monoclonal Gammopathy of Undetermined Significance (MGUS) in our study does not fall within the ranges given in most of the literature. Prevalence in our study was lower than studies done in other part of the world.

Copy Right, IJAR, 2016,. All rights reserved.

\section{Introduction:-}

Proteins are made up of amino-acids and are important components of all cells and tissues. Levels of various proteins in blood serum have a close relationship to states of health and disease, may vary due to physiological and pathological conditions. [1]

The history of electrophoresis begins in earnest with the work of Arne Tiselius in the 1930s, and new separation processes and chemical analysis techniques based on electrophoresis continue to be developed into the 21 st century. Tiselius (1937) first performed electrophoresis in fluid electrolyte. Presently, Electrophoresis is a well established and versatile technique available for separating proteins routinely used in clinical laboratories. The most commonly used method of electrophoretic protein analysis is "zone electrophoresis" on cellulose acetate. [2, 3, 4, 5] Serum Protein Electrophoresis (SPE) on cellulose acetate performed at $\mathrm{pH} 8.9$ yields five bands: one albumin and four globulins (each fraction containing a number of different proteins): alpha 1, alpha 2, beta-1, beta-2 and gamma. Serum protein electrophoresis is a method of separating proteins based on their physical properties. Serum is placed on a specific medium, and a charge is applied. The net charge (positive or negative) and the size and shape of the protein commonly are used in differentiating various serum proteins. [2, 3, 6]

Serum protein electrophoresis is mainly used to identify patients with Monoclonal gammopathy including multiple myeloma, Monoclonal gammopathy of undetermined significance (MGUS), Polyclonal gammopathy and other disorder of serum protein. Electrophoresis separates proteins based on their physical properties, and the subsets of these proteins are used in interpreting the results. [6] Plasma protein levels predictably changes in response to acute inflammation, malignancy, trauma, necrosis, infarction, burns, and chemical injury. [7] A homogeneous spikelike peak in a focal region of the gamma-globulin zone indicates a monoclonal gammopathy. [7] Monoclonal gammopathies are a group of disorders characterized by proliferation of a single clone of plasma cells that produce a homogenous M protein. Monoclonal gammopathies are malignant or potentially malignant, includes multiple myeloma, Waldenström's macroglobulinemia, solitary plasmacytoma, smoldering multiple myeloma, monoclonal gammopathy of undetermined significance, plasma cell leukemia, heavy chain disease and amyloidosis. Polyclonal gammopathies may be caused by any reactive or inflammatory process. The quantity of $M$ protein, the finding of bone marrow biopsy, and other features differentiate multiple myeloma from the other causes of monoclonal gammopathy including MGUS.[8]

The International Myeloma Working Group (IMWG) in 2003 had reviewed the criteria for diagnosis and classification with the aim of producing simple, easily used definitions based on routinely available investigations. According to IMWG, 2003 in monoclonal gammopathy of undetermined significance (MGUS) or monoclonal gammopathy, the monoclonal protein is < $30 \mathrm{~g} / \mathrm{l}$ and the bone marrow clonal cells < $10 \%$ with no evidence of multiple myeloma, other B-cell proliferative disorders or amyloidosis. In asymptomatic (smoldering) myeloma the M-protein is $>/=30 \mathrm{~g} / \mathrm{l}$ and/or bone marrow clonal cells $>/=10 \%$ but no related organ or tissue impairment (ROTI) (end-organ damage), which is typically manifested by increased calcium, renal insufficiency, anemia, or bone 
lesions (CRAB) attributed to the plasma cell proliferative process. Symptomatic myeloma requires evidence of ROTI. Non-secretary myeloma is characterized by the absence of an M-protein in the serum and urine, bone marrow plasmacytosis and ROTI. Solitary plasmacytoma of bone, extramedullary plasmacytoma and multiple solitary plasmacytomas (+/- recurrent) are also defined as distinct entities. [9]

The International Myeloma Working Group updated the disease definition of multiple myeloma in 2014 to include validated markers, three Myeloma defining events ( MDE) ( SLiM criteria for diagnosis of Multiple MyelomaClonal bone marrow plasma cells $>60 \%$ AND/OR An involved serum free light chain (kappa or lambda) $>100$ $\mathrm{mg} / \mathrm{L}$ with the ratio of the involved/uninvolved free light chains also > $100 \mathrm{mg} / \mathrm{L}$ in addition to existing requirements of $\mathrm{CRAB}$ features ( Hypercalcemia, renal failure and bone lesion) attributable to underlying clonal plasma cell disorder. [10] There was no change in criteria of MGUS. Only a new entity Light chain MGUS was included.

According to IMWG, 2014 and IMWG, 2015, Diagnostic Criteria of plasma cell dyscrasia [10] [11] Are:MGUS (monoclonal gammopathy of undetermined significance) - M-protein $<3 \mathrm{~g} / \mathrm{dL}(30 \mathrm{~g} / \mathrm{L})$ AND Clonal bone marrow plasma cells $<10 \%$ AND/ OR Urine monoclonal protein $<500 \mathrm{mg} / 24$ hours.

SMM (Smoldering Multiple Myeloma) - M-protein $\geq 3 \mathrm{~g} / \mathrm{dL}$ ( 30g/L) AND/OR Urine monoclonal protein $\geq 500$ $\mathrm{mg} / 24$ hours AND/OR Clonal bone marrow plasma cells $\geq 10 \%$, Patients with SMM may require additional imaging including PET-CT, low-dose whole body CT, or MRI of whole body or spine/pelvis

MM (Multiple Myeloma) - End-organ disease (CRAB) including one or more osteolytic lesions on radiography, but more than one lesion is required if $<10 \%$ marrow plasma cells. From MRI imaging, there must be more than one lesion of $>5 \mathrm{~mm}$ in size. AND/ OR Clonal bone marrow plasma cells $>60 \%$ AND/OR An involved serum free light chain (kappa or lambda) $>100 \mathrm{mg} / \mathrm{L}$ with the ratio of the involved/uninvolved free light chains also $>100$ $\mathrm{mg} / \mathrm{L}$ ( SLiM criteria,)

Risk factors for progression of MGUS per Mayo criteria are M-protein $>1.5 \mathrm{~g} / \mathrm{dL}(15 \mathrm{~g} / \mathrm{L})$, Non-IgG isotype (IgA or IgM) and FLC Ratio $<0.26$ or $>1.65$. Depending upon the number of risk factors present, MGUS is classified into 4 group having risk of progression at 20 years $5 \%, 21 \%, 37 \%$ and $58 \%$ respectively.

Monoclonal gammopathy of undetermined significance (MGUS) is a term originally coined by the Mayo Clinic group [12] and is defined as the presence of a monoclonal protein in the serum or urine of an individual with no evidence of multiple myeloma, AL amyloidosis, Waldenström's macroglobulinemia (WM) or other related disorders. MGUS is a plasma cell proliferative disorder that consistently precedes multiple myeloma (MM) [13, 14]. Monoclonal gammopathy of undetermined significance (MGUS) is the most common among all monoclonal gammopathies with incidence approximately 60 times greater than multiple myeloma. Monoclonal gammopathy of undetermined significance is uncommon below the age of 50 years and the prevalence increases with advancing age $[15,16,17,18]$, highest incidence is among adults age 85 years and older. MGUS is common in men than in women. [18] The risk of MGUS is higher among individuals who have first-degree relatives having either MM or MGUS. [19]. The clonal plasma cells in MGUS often contains the same chromosomal translocations and deletions that are found in full-blown multiple myeloma indicates that MGUS is an early stage of myeloma development. [20] Similar to MM, the incidence of MGUS is higher among African American and African individuals although IgM MGUS occurs less commonly in this racial group. [21, 22, 23] Most cases of MGUS (75\%) are IgG, with smaller proportions of $\operatorname{IgM}(15 \%)$ and $\operatorname{IgA}(10 \%)$. Every year approximately $1 \%$ of patients with MGUS develop a symptomatic plasma cell neoplasm, usually multiple myeloma. [24] These patients require close follow-up due to its increased risk for progression to malignant diseases as progression to multiple myeloma is unpredictable and there is no plateau time, beyond which development of a condition such as multiple myeloma will not occur. So, Periodic (usually annual) monitoring should be done (with serum protein electrophoresis, immunoglobulins and complete blood count) to assess serum $\mathrm{M}$ component levels and Bence Jones proteinuria.

The prevalence of monoclonal gammopathy of undetermined significance has been reported variously in medical literature. The status of its prevalence in India $\&$ in our part of the country (North India) has been under reported. This study was conducted with the aim of evaluating the elderly individuals (age $>50$ yrs) with abnormal serum protein electrophoresis pattern and correlating it with other parameters, specially liver function tests and kidney function tests, to differentiating the different conditions of abnormal serum protein electrophoresis e.g. monoclonal 
gammopathy, polyclonal gammopathy, Hypoalbunemia, nephrotic syndrome, chronic inflammation, alpha-1 antitrypsin deficiency, hypogammaglobulinemia, cirrhosis, G.I. loss, liver disease, acute inflammation etc. The basic purpose of this study was to identify the cases of monoclonal gammopathy specially monoclonal gammopathy of undetermined significance and differentiate it from other causes of monoclonal gammopathy e.g. multiple myeloma, Waldenström's macroglobulinemia, solitary plasmacytoma, smoldering multiple myeloma, plasma cell leukemia, heavy chain disease, amyloidosis etc. Above the all the main objective was to screen the elderly persons for Mprotein by serum protein electrophoresis and to evaluate the current status of prevalence of monoclonal gammopathy of undetermined significance [MGUS] in our part of country.

\section{Materials and Methods:-}

This work was carried out in the Department of Pathology, Darbhanga Medical College and Hospital, Laheriasarai during the period from August 2010 to September 2012. Total 200 elderly individuals of age more than 50 years comprising of equal number of males (100) and females (100) were included in our study. The selection of cases was done on random basis and it comprises mostly from the patients and attendants of the patients attending the indoor and outdoor of various department of the Darbhanga Medical College and Hospital, Laheriasarai, including the Department of pathology.

Following detail history taking and physical examination, venous blood sample was collected with proper aseptic care. Collected sample is kept in test tube for completion of coagulation process and serum was obtained after centrifugation of the clotted blood. Fresh serum without hemolysis was used. Each serum sample was subjected to Serum protein electrophoresis and total protein estimation. Each individuals were also evaluated for other parameters e.g. CBC, Liver function test, kidney function test, hematological tests and others. Among laboratories tests Total Serum protein (Biuret Method, End Point), Serum Albumin (BCG Dye Method, End Point), Serum Globulin, Serum Bilirubin (Total, Indirect and Direct Bilirubin) (Diazo Method End Point) SGPT (IFCC Method, Kinetic), SGOT (IFCC Method, Kinetic), Alkaline phosphatase (Tris Carbonate Buffer, Kinetic), Blood urea (BUN) (GLDH- UREASE METHOD, INITIAL RATE), Serum creatinine (CRE) (Jaffe's Method, Initial Rate) and Bence Jones protein in urine were done. Among hematological test CBC, PBS, ESR and Bone marrow examination were done.

\section{Principle of electrophoresis:-}

Every molecule possesses an electrical charge due to the presence of both positively charged groups and negatively charged groups and the net charge dictates the migration characteristics of the species at a given $\mathrm{pH}$. Electrophoresis is a method by which electrically charged particles of a mixture of substances are separated under an electric field. The positively charged particles migrate towards anode and the rate of migration of ion in an electric field depends on the number of factors including shape, size, net charge and salvation of the ions, viscosity of the solution and magnitude of current applied. As a result of different rate of migration, a mixture of proteins (such as plasma or serum) can be separated into a number of fractions having similar mobility. With the Interlab SPE procedure, proteins are separated at an alkaline $\mathrm{pH}(8.7)$ using the principle of zone electrophoresis on a suitable support medium: cellulose acetate. When the migration is complete, the proteins are then stained with Ponceau S Red, destained and cleared to have a transparent background for the patterns. [25] The strip is then scanned and the Densitometric results are displayed together with the graph.

Serum Protein Electrophoresis was performed using appliances Genio $\mathrm{S}$ is a smallest fully automated system for Electrophoresis of size measures, $46 \times 41 \times 42 \mathrm{~cm}$, engineered in such a way that everything needed is in one piece. Migration chamber, reagent tanks, dryer, sample plate, an 8 independent channels densitometer, a microcontroller, LCD display, and keyboard are built in the equipment. Data System visualize, edit, and correct all information received by the Genio. All phases of the electrophoretic process were constantly monitored. The Operator's Manual was referred for correct addition of ready to use reagents to the Instrument Reagent Rack. Strips are of Cellulose Acetate supported on Mylar R, Soaking and Running Buffer contains: 1.0\% Tris (hydroxymthyl)-aminomethan, 0.5\% 5, 5-diethyl barbituric acid sodium salt, Staining Solution contains: Ponceau S Red, 1-5\% Trichloroacetic acid, Destaining Solution contains: Citric Acid, 2.5\% (w/v) and clearing Solution contains: 32\% N-Methil-2-pyrrolidone, 8.0\% Ethanol, 7.0\% Acetic acid, 1.0\% Methanol. Materials provided for the GENIO instrument 192 tests was Kit Product Number: SRE186K. Serological pipettes preferably pipetting devices for delivery of $30 \mu \mathrm{L}, 1 \mathrm{~mL}, 2 \mathrm{~mL}$, and $2.3 \mathrm{~m}$, distilled (DI) water and membrane filter system. 
The basic steps of a serum protein electrophoresis were followed. The Myler backed dry cellulose acetate strip is soaked slowly in the buffer. The excess of buffer is removed from the strip. $30 \mu \mathrm{L}$ of serum sample is loaded on the strip. Electrophoretic separation of the fractions is performed in the migration chamber. The strip is dipped in the stain solution where the proteins are fixed permanently on the support and bind the dye. The dye also binds weakly to the support giving the background staining. The strip is destained to remove the dye bound to the support until the electrophoretic pattern is visualized. The strip is then transferred into the clearing solution. The strip is placed in a dryer to accelerate the evaporation of clearing solution until the strip becomes transparent. Quantification of the dye associated with the bands is accomplished by scanning the strip in a measuring optical system (Densitometer). The graph, obtained by software elaboration of Densitometric data, displays the percentage value of each fraction. Visual inspection and interpretation of serum proteins is done by comparing sample pattern with that of a control serum.

\section{Observations:-}

The main findings in this study were:-

Out of 200 hundred cases, $100(50 \%)$ cases were in age group of $\geq 50-60$ years, $60(30 \%)$ cases were in age group of $>60-70$ years and $40(20 \%)$ cases were of $>70$ years. Out of 200 cases $100(50 \%)$ were male and $100(50 \%)$ were female. Out of 100 male cases, 54(27\%) cases were in age group $\geq 50-60$ years, $26(13 \%)$ cases were in age group $>60-70$ years and $18(9 \%)$ cases were in age group >70years. Out of 100 female cases, 46 cases (23\%) were of age group $\geq 50-60$ years, 34 cases $(17 \%)$ were of age group of $>60-70$ years and 22 cases $(11 \%)$ were of $>70$ years. (Table No.-1)

Out of 200 hundred cases, 172 cases (86\%) had normal serum protein electrophoresis finding were as 28 (14\%) cases had abnormal serum protein electrophoresis interpretation. Out of 172 cases with normal SPE finding 83 $(41.5 \%)$ cases were males and $89(44.5 \%)$ cases were females. Out of 28 cases of abnormal SPE pattern $17(8.5 \%)$ cases were males and 11(5.5\%) cases were females. (Table No.-2)

Out of 172 cases with normal SPEP finding $91(45.5 \%)$ cases were of age group $\geq 50$ - 60 years, 47(23.5\%) cases were of age group $\geq 50$ - 60 years, and 34(17\%) cases were of age group >70years. Out of 28 cases of abnormal SPEP pattern $9(4.5 \%)$ cases were of age group $\geq 50$ - 60 years, $13(6.5 \%)$ cases were of age group of $>60-70$ years and $6(3 \%)$ cases were of age group $>70$ years. (Table No.-3)

Out of $28(14 \%)$ cases with abnormal serum protein electrophoresis interpretation 3(1.5\%) cases had Monoclonal gammopathy, 20 (10\%) cases had Polyclonal gammopathy and 5(2.5\%) cases had Hypoalbuminemia. Out of 3 cases of Monoclonal gammopathy, $1(0.5 \%)$ case was of age group $>60-70$ years and $2(1 \%)$ cases were of age group $>70$ years. Out of 20 cases of Polyclonal gammopathy 7(3.5\%) cases were of age group $\geq 50$ - 60 years, 9(4.5\%) cases were of age group $>60-70$ years, and $4(2 \%)$ cases were of age group $>70 y e a r s$. Out of 5 cases of Hypoalbuminemia, $1(0.5 \%)$ case was of age group $\geq 50-60$ years, $3(1.5 \%)$ cases were of age group $>60-70$ years, and $1(0.5 \%)$ case was of age group >70years. (Bar chart No.-1)

Out of 3 cases of monoclonal gammopathy $2(1 \%)$ cases were male and $1(0.5 \%)$ case was female. Out of 20 cases of Polyclonal gammopathy $12(6 \%)$ cases were male and $8(4 \%)$ cases were female. Out of 5 cases of Hypoalbuminemia, 3(1.5\%) cases were male and $2(1 \%)$ cases were female. (Bar Chart No.-2)

Out of 3 cases of Monoclonal gammopathy, 2(1\%) cases were of MGUS, $1(0.5 \%)$ case was of Multiple Myeloma and no cases of other monoclonal gammopathy were found in our study group. Out of 2 (1\%) cases of Monoclonal gammopathy of Undetermined Significance, $1(0.5 \%)$ case was of age group $>60-70$ years and $1(0.5 \%)$ case was of age group $>70$ years. No cases of MGUS were detected in age group of $\geq 50$ - 60 years. $1(0.5 \%)$ case of multiple myeloma was of age group >70years. (Bar Chart No.-3)

Out of 3 cases of Monoclonal gammopathy 2(1\%) cases were of MGUS, $1(0.5 \%)$ case was of Multiple Myeloma. No cases of other monoclonal gammopathy were found in our study group. Out of 2 cases of MGUS 1(0.5\%) case was male and $1(0.5 \%)$ case was female were as $1(0.5 \%)$ case of Multiple Myeloma detected was male. (Bar Chart No.-4)

Both 2 cases of Monoclonal gammopathy of undetermined significance had normal level of S. bilirubin. Only case of MM had also normal level of S. bilirubin. All the 20 cases of PG had also normal level of S. bilirubin. Out of 5 cases of Hypoalbuminemia 1 case had normal level of S. bilirubin; where as other 4 cases had increased S. bilirubin 
level. Both 2 cases of Monoclonal gammopathy of undetermined significance had normal level of SGOT. Only case of MM had also normal SGOT level. All the 20 cases of PG had also normal level of SGOT. Out of 5 cases of Hypoalbuminemia, 1 case had normal level of SGOT; where as other 4 cases had increased SGOT level. Both 2 cases of Monoclonal gammopathy of undetermined significance had normal level of SGPT. Only case of MM had also normal SGPT level. All the 20 cases of PG had also normal level of SGPT. Out of 5 cases of Hypoalbuminemia 1 case had normal level of SGPT; where as other 4 cases had increased SGPT level. Both 2 cases of Monoclonal gammopathy of undetermined significance had normal level of ALP. Only case of MM had normal ALP level. All the 20 cases of PG had also normal level of ALP. All the 5 cases of Hypoalbuminemia had normal level of ALP. (Table No.-4)

Both 2 cases of Monoclonal gammopathy of undetermined significance (MGUS) had normal level of Serum creatinine. Only case of MM had increased Serum creatinine level. All the 20 cases of PG had also normal level of Serum creatinine. Out of 5 cases of Hypoalbuminemia 4 cases had normal level of Serum creatinine; whereas 1 case had raised Serum creatinine level. Both 2 cases of Monoclonal gammopathy of undetermined significance (MGUS) had normal level of Blood urea. Only case of MM had raised Blood urea level. All the 20 cases of PG had also normal level of Blood urea. Out of 5 cases of Hypoalbuminemia 4 cases had normal level of Blood urea; whereas 1 case had increased Blood urea level. (Table No.-5)

Out of 2 cases of Monoclonal gammopathy of undetermined significance, 1 case had normal total serum protein level and 1 case had increased level of total serum protein. Only case of MM had increased level of total serum protein. Out of 20 cases of PG, 17 cases had normal level of total serum protein and 3 cases had increased level of total serum protein. Out of 5 cases of Hypoalbuminemia, 2 cases had normal level of total serum protein and 3 cases had decreased level of total serum protein. (Table No.-6)

Out of 2 cases, 1 case of Monoclonal gammopathy of undetermined significance had normal level of serum albumin level and 1 case had decreased level of serum albumin. Only case of MM had decreased level of serum albumin. Out of 20 cases of PG, 13 cases had normal level of serum albumin and 7 cases had decreased level of serum albumin. All the 5 cases of Hypoalbuminemia had decreased level of serum albumin. (Table No.-7)

Both 2 cases of Monoclonal gammopathy of undetermined significance (MGUS) had increased level of Serum gamma globulin. Only case of MM had increased Serum gamma globulin level. All 20 cases of PG had increased Serum gamma globulin level. Out of 5 cases of Hypoalbuminemia, 2 cases had increased level of serum gamma globulin level and 3 cases had decreased level of serum gamma globulin. (Table No. -8 )

Table No.1:- Age \& Sex distribution of study group.

\begin{tabular}{|c|c|c|c|}
\hline $\begin{array}{c}\text { Age group } \\
\text { (years) }\end{array}$ & $\begin{array}{c}\text { Total no. } \\
\text { of patients N\& (\%) }\end{array}$ & $\begin{array}{c}\text { No. of males } \\
\mathbf{N} \&(\%)\end{array}$ & $\begin{array}{c}\text { No. of females } \\
\mathbf{N} \boldsymbol{\&}(\boldsymbol{\%})\end{array}$ \\
\hline$\geq 50-60$ & $100(50)$ & $54(27)$ & $46(23)$ \\
\hline$>60-70$ & $60(30)$ & $26(13)$ & $34(17)$ \\
\hline$>70$ & $40(20)$ & $18(9)$ & $22(11)$ \\
\hline
\end{tabular}

Table No.2:- Different interpretations of Serum Protein Electrophoresis (SPEP) in elderly individuals (>50years) and their sex distribution.

\begin{tabular}{|l|c|c|c|c|c|c|}
\hline \multirow{2}{*}{ Group } & \multicolumn{2}{|c|}{ Total No. of patients } & \multicolumn{2}{c|}{ Males } & \multicolumn{2}{c|}{ Females } \\
\cline { 2 - 7 } & $\mathrm{N}$ & $(\%)$ & $\mathrm{N}$ & $(\%)$ & $\mathrm{N}$ & $(\%)$ \\
\hline Normal SPEP & 172 & 86 & 83 & 41.5 & 89 & 44.5 \\
\hline Abnormal SPEP & 28 & 14 & 17 & 8.5 & 11 & 5.5 \\
\hline
\end{tabular}

Table No.3:- Different interpretations of Serum Protein Electrophoresis (SPEP) in elderly individuals (>50years) and their age distribution.

\begin{tabular}{|l|c|c|c|}
\hline \multirow{2}{*}{ Group } & \multicolumn{3}{|c|}{ Age (in years) N \& (\%) } \\
\cline { 2 - 4 } & $\geq 50-60$ & $>60-70$ & $>70$ \\
\hline Normal SPEP & $91(45.5)$ & $47(23.5)$ & $34(17)$ \\
\hline Abnormal SPEP & $9(4.5)$ & $13(6.5)$ & $6(3)$ \\
\hline
\end{tabular}



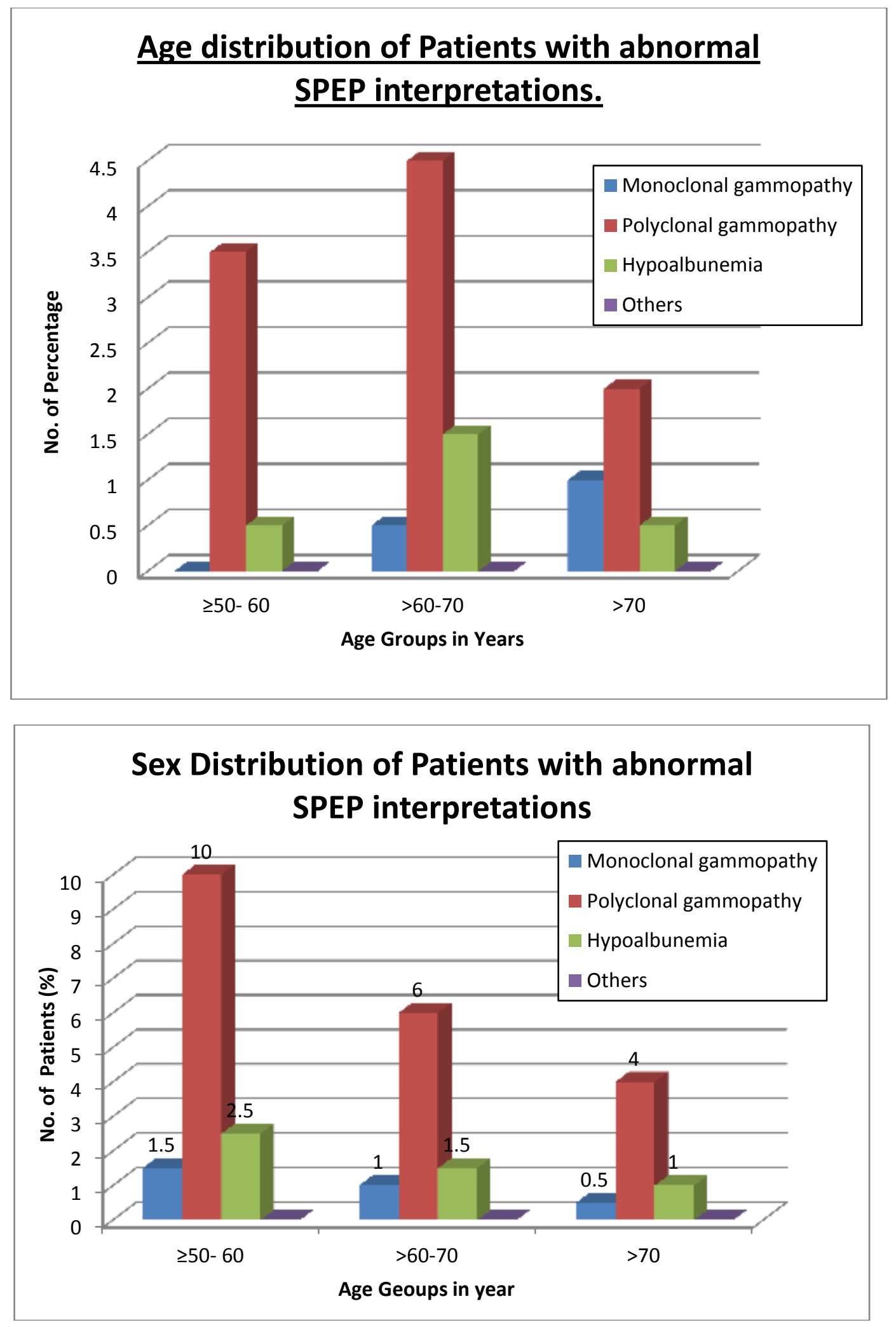


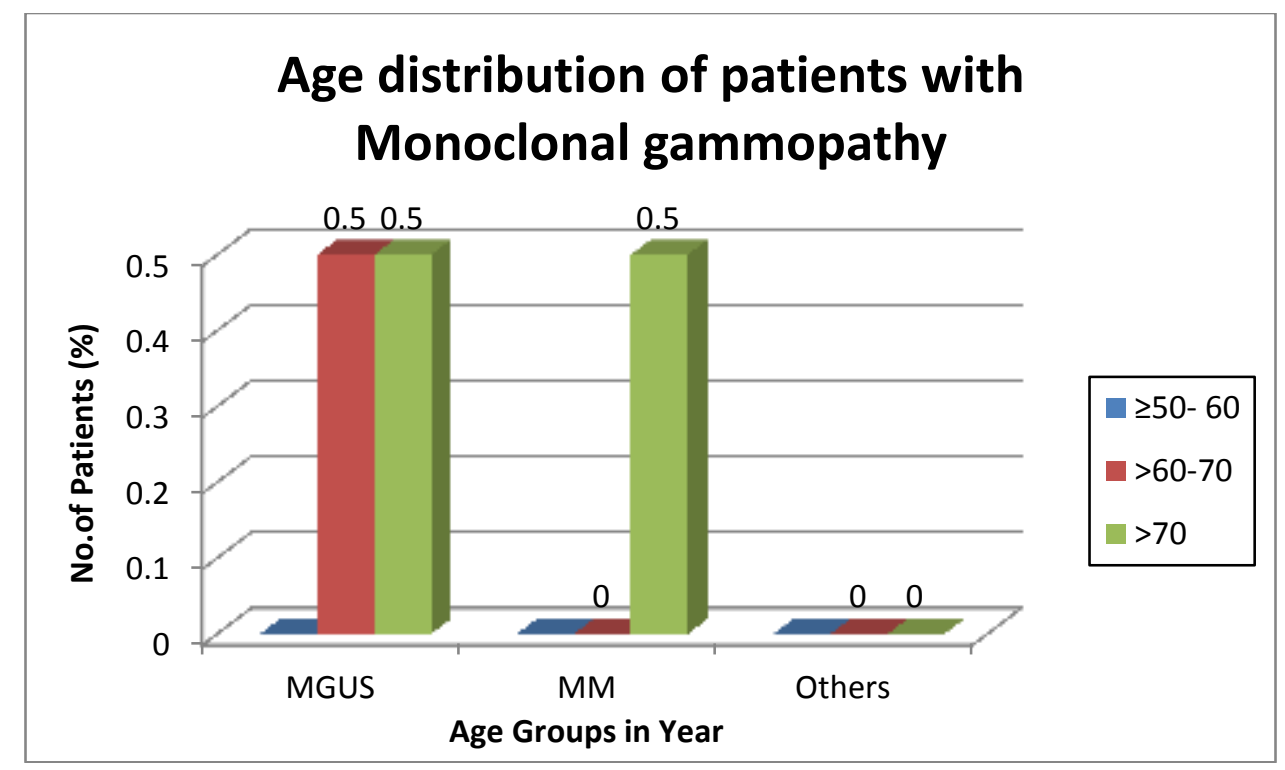

\section{Sex distribution of Monoclonal gammopathy in elderly individuals (>50years)}

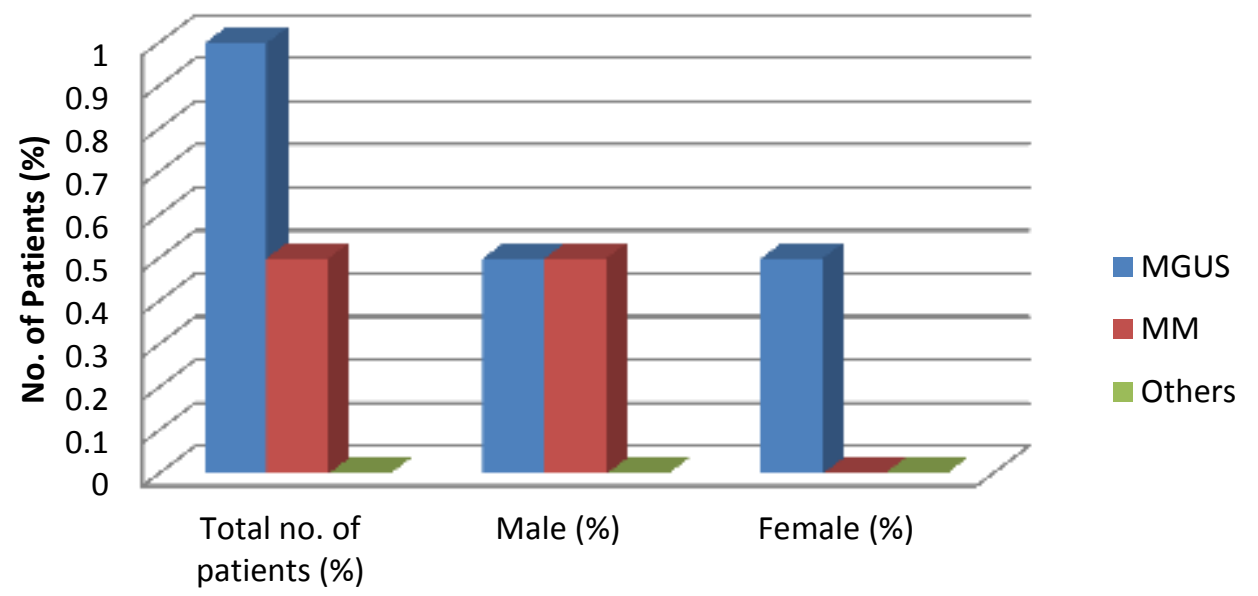

Age Groups in Years

Table No.4:- Liver Function Test [Serum bilirubin, SGOT, SGPT\& Alkaline phosphatase (ALP) levels] in our study.

\begin{tabular}{|l|l|l|l|l|l|l|l|l|}
\hline \multirow{3}{*}{ Group } & $\begin{array}{l}\text { S. Bilirubin (in } \\
\text { mg/dl), N \& }(\%)\end{array}$ & $\begin{array}{l}\text { SGOT (IU/L ), } \\
\text { N\& (\%) }\end{array}$ & $\begin{array}{l}\text { SGPT (IU/L), } \\
\text { N\& (\%) }\end{array}$ & \multicolumn{2}{l|}{$\begin{array}{l}\text { ALP (IU/L ), } \\
\text { N\& (\%) }\end{array}$} \\
\cline { 2 - 8 } & $\begin{array}{l}\text { Normal } \\
\text { level }\end{array}$ & $\begin{array}{l}\text { Increas } \\
\text { ed }\end{array}$ & $\begin{array}{l}\text { Normal } \\
\text { level }\end{array}$ & $\begin{array}{l}\text { Increas } \\
\text { ed }\end{array}$ & $\begin{array}{l}\text { Normal } \\
\text { level }\end{array}$ & $\begin{array}{l}\text { Increase } \\
\text { d }\end{array}$ & $\begin{array}{l}\text { Normal } \\
\text { level }\end{array}$ & $\begin{array}{l}\text { Increa } \\
\text { sed }\end{array}$ \\
\hline MGUS (2) & $2(1)$ & - & $2(1)$ & - & $2(1)$ & - & $2(1)$ & - \\
\hline MM(1) & $1(0.5)$ & - & $1(0.5)$ & - & $1(0.5)$ & - & $1(0.5)$ & - \\
\hline PG(20) & $20(10)$ & - & $20(10)$ & - & $20(10)$ & - & $20(10)$ & - \\
\hline HA(5) & $1(0.5)$ & $4(2)$ & $1(0.5)$ & $4(2)$ & $1(0.5)$ & $4(2)$ & $5(2.5)$ & - \\
\hline NSPEP(172) & $172(86)$ & - & $172(86)$ & - & $172(86)$ & - & $172(86)$ & - \\
\hline
\end{tabular}

- Normal Total Serum Bilirubin level - $0.1-1.2 \mathrm{mg} / \mathrm{dl}$ 
- Conjugated bilirubin level $-0-0.3 \mathrm{mg} / \mathrm{dl}$.

- Normal Total S.G.O.T. level -5-35 IU/L.

- Normal Total S.G.P.T. level -5-40 IU/L.

- Normal Total ALP level -30-130 IU/L.

Table No 5:- Renal Function Test [Serum creatinine \& Blood urea levels] in our study.

\begin{tabular}{|l|l|l|l|l|}
\hline \multirow{2}{*}{ Group } & \multicolumn{2}{|l|}{ Serum creatinine (in mg/dl), N \& (\%) } & \multicolumn{2}{l|}{ Blood urea (in mg/dl), N \& (\%) } \\
\cline { 2 - 5 } & Normal level & Increased & Normal level & Increased \\
\hline MGUS(2) & $2(1)$ & - & $2(1)$ & - \\
\hline MM(1) & - & $1(0.5)$ & - & $1(0.5)$ \\
\hline PG(20) & $20(10)$ & - & $20(10)$ & - \\
\hline HA(5) & $4(0.5)$ & $1(0.5)$ & $4(0.5)$ & $1(0.5)$ \\
\hline NSPE(172) & $172(86)$ & - & $172(86)$ & - \\
\hline
\end{tabular}

- Normal Serum creatinine level - 0.7-1.4 mg/dl (for male)

- $\quad 0.6-1.2 \mathrm{mg} / \mathrm{dl}$ (for female)

- Normal Blood urea level $-13-45 \mathrm{mg} / \mathrm{dl}$.

Table No 6:- Total Serum protein levels in our study.

\begin{tabular}{|c|c|c|c|}
\hline \multirow{2}{*}{ Group } & \multicolumn{3}{|c|}{ Total serum protein, N \& $(\%)$} \\
\cline { 2 - 4 } & Normal (6-8.3gm/dI) & Increased(>8.3gm/dl) & Decreased(<6 gm/dI) \\
\hline MGUS & $1(0.5)$ & $1(0.5)$ & - \\
\hline MM & - & $1(0.5)$ & - \\
\hline PG & $17(8.5)$ & $3(1.5)$ & $3(1.5)$ \\
\hline HA & $2(1)$ & - & - \\
\hline NSPE & $172(86)$ & - & \\
\hline
\end{tabular}

- Normal Total serum protein level -6-8.3 gm/dl.

Table No. 7:- Serum albumin levels in our study.

\begin{tabular}{|c|c|c|}
\hline \multirow{2}{*}{ Group } & \multicolumn{2}{|c|}{ S. Albumin level, N \& (\%) } \\
\cline { 2 - 3 } & Normal (3.2-5.0gm/dl) & Decreased(<3.2 gm/dl) \\
\hline MGUS & $1(0.5)$ & $1(0.5)$ \\
\hline MM & - & $1(0.5)$ \\
\hline PG & $13(6.5)$ & $7(3.5)$ \\
\hline HA & - & $5(2.5)$ \\
\hline NSPEP & $172(86)$ & - \\
\hline
\end{tabular}

- Normal serum level of albumin - 3.2-5.0 gm/dl.

Table No 8:- Different serum globulin fractions in our study.

\begin{tabular}{|c|c|c|c|c|c|c|c|c|c|c|c|c|}
\hline \multirow[t]{2}{*}{ Group } & \multicolumn{12}{|c|}{ Different serum globulin fractions in our study, N\& (\%) } \\
\hline & $\begin{array}{l}\text { Alph } \\
\text { a } \\
1(\mathbf{N})\end{array}$ & $\begin{array}{l}\text { Alph } \\
\text { a 1 } \\
(\uparrow)\end{array}$ & $\begin{array}{l}\text { Alph } \\
\text { a 1 } \\
(\downarrow)\end{array}$ & $\begin{array}{l}\text { Alph } \\
\text { a } \quad 2 \\
\text { (N) }\end{array}$ & $\begin{array}{l}\text { Alph } \\
\text { a } \\
2(\uparrow)\end{array}$ & $\begin{array}{l}\text { Alph } \\
\text { a } 2 \\
(\downarrow)\end{array}$ & $\begin{array}{l}\text { Beta } \\
\text { (N) }\end{array}$ & $\begin{array}{l}\text { Bet } \\
\text { a } \\
(\uparrow)\end{array}$ & $\begin{array}{l}\operatorname{Beta}(\downarrow \\
)\end{array}$ & $\begin{array}{l}\text { Gamm } \\
\text { a }(\mathbf{N})\end{array}$ & $\begin{array}{l}\text { Gamm } \\
\text { a }(\uparrow)\end{array}$ & $\begin{array}{l}\text { Gamma( } \\
\downarrow)\end{array}$ \\
\hline $\begin{array}{l}\text { MGU } \\
\text { S }\end{array}$ & $2(1)$ & - & - & $2(1)$ & - & - & 2(1) & - & - & - & $2(1)$ & - \\
\hline $\mathbf{M M}$ & $\begin{array}{l}1 \\
(0.5)\end{array}$ & - & - & $\begin{array}{l}1 \\
(0.5)\end{array}$ & - & - & $\begin{array}{l}1 \\
(0.5)\end{array}$ & - & - & - & $1(0.5)$ & - \\
\hline PG & $\begin{array}{l}20 \\
(10)\end{array}$ & - & - & $\begin{array}{l}20 \\
(10)\end{array}$ & - & - & $\begin{array}{l}20 \\
(10)\end{array}$ & - & - & - & $\begin{array}{l}20 \\
(10)\end{array}$ & - \\
\hline HA & $\begin{array}{l}5 \\
(2.5) \\
\end{array}$ & - & - & $\begin{array}{l}5 \\
(2.5) \\
\end{array}$ & - & - & $\begin{array}{l}5(2.5 \\
) \\
\end{array}$ & - & - & - & $2(1)$ & $3(1.5)$ \\
\hline NSPE & $\begin{array}{l}172 \\
(86)\end{array}$ & - & - & $\begin{array}{l}172 \\
(86)\end{array}$ & - & - & $\begin{array}{l}172 \\
(86)\end{array}$ & - & - & $\begin{array}{l}172 \\
(86)\end{array}$ & - & - \\
\hline
\end{tabular}


Reference values of Normal Serum Protein Electrophoresis

\begin{tabular}{|c|c|c|}
\hline Fraction & Reference range (\%) & Normal Values( g/dl) \\
\hline Albumin & $52.0-68.0$ & $3.5-5.0$ \\
\hline Alpha 1 & $2.0-5.0$ & $0.1-0.3$ \\
\hline Alpha 2 & $6.6-13.5$ & $0.6-1.0$ \\
\hline Beta & $8.5-14.5$ & $0.7-1.2$ \\
\hline Gamma & $11.0-21.0$ & $0.7-1.6$ \\
\hline
\end{tabular}

\section{Discussion:-}

In our study total 200 cases having equal number of male and female i.e. $100(50 \%)$ of each in this study, 100 $(50 \%)$ of cases were of age group $\geq 50-60$ years, $60(30 \%)$ of cases were of age group $>60-70$ years and $40(20 \%)$ cases were of age group $>70$ years. Abnormal SPEP interpretation was observed in $28(14 \%)$ cases were as normal serum protein electrophoresis pattern was observed in rest of 172 cases. Out of these 28 cases, 3 (1.5\%) cases were of Monoclonal Gammopathies, 20(10\%) cases were of Polyclonal Gammopathies and 5(2.5\%) cases were of Hypoalbuminemia. Out of $3(1.5 \%)$ cases of monoclonal gammopathy, $2(1 \%)$ cases were of MGUS and $1(0.5 \%)$ case was of MM. The prevalence of monoclonal gammopathies was found to be higher in older individuals (out of 3 cases, 2 were of age more than 60 years of age whereas 1 case was in the age group $\geq 50-60$ years). Mean age of cases having monoclonal gammopathy was 69.66 years. Out of 20(10\%) cases of Polyclonal Gammopathy, 7(3.5\%) cases were of age group $\geq 50-60$ years, $9(4.5 \%)$ cases were observed in age group $>60-70$ years where as $4(2 \%)$ cases in age group $>70$ years. Out of total 20 patients of PG, 12 cases were males and 8 cases were females. All cases of PG had LFT and KFT within normal limit. Mean age of cases having polyclonal gammopathy was 64.75 years. Out of 3 cases of monoclonal gammopathy, 2 cases were males and 1 case was female, thus male: female ratio in our study was $2: 1$. In case of polyclonal gammopathy group, out of total 20 patient's males and females were 12 and 8 respectively thus male: female ratio was 1.5:1. Both 2 cases of Monoclonal Gammopathy of Undetermined Significance (MGUS) had M pike with normal liver and kidney function test. Only case of Multiple Myeloma (MM) detected in our study had normal liver function, deranged renal function and $M$ pike in Serum Protein Electrophoresis. One case of Hypoalbuminemia had deranged KFT and 4 cases of Hypoalbuminemia had deranged LFT. Rest of cases had normal KFT and LFT. Only case of Multiple Myeloma (MM) detected in our study had normal liver function, deranged renal function and $\mathrm{M}$ pike in Serum Protein Electrophoresis. Out of 5(1.5\%) cases of Hypoalbunemia, 4(2\%) cases had deranged liver function test and $1(0.5 \%)$ case had deranged kidney function tests. Out of 5(1.5\%) cases, 2(1\%) cases of Hypoalbuminemia had Hypergammaglobulinemia and 3(1.5\%) cases had Hypogammaglobulinemia.

Similar studies were also conducted by other worker. Average specific incidence rates are increasing sharply with age, independent of gender or race with a slightly lower rate being reported in UK, Eastern Europe, South America, India, and Japan. Geographical variation tends to exist with monoclonal gammopathies. Prevalence observed in our population in this study is slightly lower than seen in other parts.

In a largest study conducted by Kyle in the white population in Olmsted County, Minnesota, Kyle found the prevalence of MGUS to be $3.2 \%$ in persons over 50 years of age and prevalence increased with age i.e. $5 \%$ in those over 70 years while in the over-85 age group the prevalence was $7.5 \%$ and nearly $9 \%$ of males aged 85 years and older were diagnosed with this condition with a slight male predominance (4.0\% vs. $2.7 \%$ ). Of these, $68.9 \%$ had an IgG M-protein, $17 \cdot 2 \% \operatorname{IgM}$ and $10.8 \%$ IgA. The light chain was kappa in $62 \%$ and lambda in $38 \%$ and monoclonal light chains were detected in the urine in $21 \cdot 5 \%$ [18].

A study of monoclonal protein levels in 917 men (50-74 years) was conducted between September 1, 2004, and September 30, 2006 in Ghana showed a prevalence of MGUS of approximately 5.9\% in African men over the age of 50. Serum samples from all participants were analyzed by electrophoresis performed on agarose gel. Age-adjusted and standardized (to the 2000 world population) prevalence estimates of MGUS and 95\% confidence intervals (CIs) were computed in the Ghanaian men and compared with MGUS prevalence in 7996 white men from Minnesota. Of the 917 study participants, 54 were found to have MGUS, yielding an age-adjusted prevalence of 5.84 (95\% CI, 4.27-7.40) per 100 persons. No significant variation was found by age group, ethnicity, education status, or prior infectious diseases. Compared with white men, the age-adjusted prevalence of MGUS was 1.97 -fold (95\% CI, 1.942.00) higher in Ghanaian men. [26] 
In a comparative study of elderly black and white population conducted in Duke, North Carolina, USA, Cohen et al have reported prevalence of monoclonal gammopathy as $6.1 \%$ with a greater than 2 times difference between blacks $(8.4 \%)$ and whites $(3.8 \%)$.[22] in our study prevalence of monoclonal gammopathy was $1.5 \%$, which is lower than study conducted by Cohen.

In a study conducted at the tertiary care hospital in North India, the prevalence of monoclonal gammopathy was observed in $7.5 \%$ of patients. Prevalence of monoclonal gammopathy observed in our study $1.5 \%$ is lower than North Indian urban population study the median patient age observed in study of patients visiting hospitals in Delhi was 56 years, which was found to be lower as compared to that of our study which was 60 years. [21]

The median age reported by earlier studies conducted was 70 years at diagnosis (range: 53-90). Mean age of presentation in our study was 69.66 years whereas as Median age was 71 years which was slight higher in comparison to that reported in most of earlier studies.

The median age as reported in a study done at Spanish health center was 73 years. The age of presentation in our study was slight lower i.e., Mean age was 60 years, whereas Median age was 71 years. The prevalence of monoclonal gammopathy was found to be slightly higher in men, in our study (men: women ratio being 2:1), which was not consistent with a study conducted by Enrique et al in Spanish population, where men: women ratio was reported to be $1: 1.3$.

Our observation is consistent with the findings by Shafi et al in Indian Kashmiri population where a higher prevalence was observed in men as compared to women $(1.4: 1)$.

In a health survey in a county in Sweden, which included $79 \%$ of people above 25 years of age, $0.9 \%$ of the population were found to have an M-protein detected by paper protein electrophoresis [15], which is lower than our study i.e. in $1.5 \%$.

In a French study of 30279 members of a health care programme, the M-protein was detected in $1 \cdot 1 \%$ as they had used the more sensitive technique of agarose gel electrophoresis which is lower than our study. [17]

In a study conducted in Italy hospitalized patients were screened, M-proteins were found in $0 \cdot 7 \%$. [27]

In a study among hospitalized patients in North America M-proteins were found in 1.2\% [28].

In one study of 111 residents of a retirement home in Carolina, monoclonal bands were found in $14 \%$ over the age of 90 years [29].

Monoclonal immunoglobulins (M-proteins or paraproteins) can be detected in the serum of about $1 \%$ of the population overall [15] and most will be classified as MGUS (reviewed in detail in [30] and [31] following the exclusion of other conditions associated with monoclonal immunoglobulins.

In Caucasian population, MGUS affects about 3\% of individuals > 70 years of age, whereas in Mexican mestizos this figure is substantially lower $(0.7 \%)$; on the other hand, MGUS represents in Mexico only $2.4 \%$ of all monoclonal gammopathies. In a total of 9081 individuals studied prospectively at the Centro de Hematología y Medicina Interna de Puebla throughout a 20-year period, 11 patients with MGUS was identified (Ruiz-Delgado GJ, Gómez Rangel JD.). Median age was 70 years (range 43-83 years). MGUS, like other monoclonal gammopathies, is less frequent in Mexican mestizos than in Caucasians.

In a study done to evaluate the incidence and evolution of MGUS in a Greek population, 1564 consecutive patients older than 50 years who were admitted to the Department of Clinical Therapeutics at the University Of Athens School Of Medicine for various reasons over a 26-month period were evaluated with serum protein electrophoresis. Cases in which a monoclonal protein was detected, a panel of tests was performed to rule out an underlying plasma cell malignancy (PCM). The incidence of MGUS was $4 \%$ and there was a positive correlation with increasing age. The median value of serum M peak was only $5.3 \mathrm{~g} / \mathrm{l}$. [32]

In a study of 52,802 persons in Nagasaki City, Japan [33] conducted from October 1, 1988, to March 31, 2004, a total of 52,802 (of 71,675) Japanese survivors of the atomic bomb explosion were screened for M protein. A 2 -step screening was performed with a serum protein electrophoresis followed by immunoelectrophoresis and a 
quantitative determination of serum concentration of immunoglobulins. Monoclonal gammopathy of undetermined significance was identified in 1088 of the 52,781 study participants. The overall prevalence of MGUS was $2.1 \%$ $(1.9 \%-2.2 \%)$ in the total population screened and $2.4 \%(2.0 \%-2.6 \%)$ in those 50 years or older. The prevalence was significantly higher in men than in women $(2.8 \%$ vs. $1.6 \%)$. In both sexes, the prevalence rose with increasing age from $1.0 \%$ in participants aged 42 to 49 years, $1.9 \%$ in those 50 to 59 years, $2.6 \%$ in those 60 to 69 years, and $3.0 \%$ in those 70 to 79 years, to $4.4 \%$ in those 80 years and older. The heavy chain isotypes of immunoglobulin were IgG in $73.6 \%$ of patients, $\operatorname{IgA}$ in $17.7 \%$, IgM in $7.5 \%$, and oligoclonal gammopathies in $1.1 \%$. The prevalence of MGUS is lower in this Japanese population than that reported in Western countries among people older than 60 years, especially among women.

Our data of prevalence of MGUS are consistent with those of other epidemiological studies using cellulose acetate electrophoresis to identify monoclonal M protein in healthy population. Prevalence of MGUS in our study is lower than in other series using Immunoelectrophoresis to identify M protein as Immunoelectrophoresis is more sensitive procedure than Cellulose Acetate Zonal Electrophoresis. Prevalence of MGUS in our study is also lower than the data of those other series in which hospital based populations or population suspected to have increased M protein levels were observed.

\section{Conclusion:-}

In conclusion, Prevalence of overall Monoclonal Gammopathy, Multiple Myeloma (MM) and that of Monoclonal Gammopathy of Undetermined Significance (MGUS) in our part of country were $1.5 \%, 1 \%$ and $0.5 \%$ respectively. Prevalence of Monoclonal Gammopathy, Multiple Myeloma (MM) and Monoclonal Gammopathy of Undetermined Significance (MGUS) in our study does not fall within the ranges given in most of the literature. The findings of our study suggest that North Indian elderly population in Bihar have lower prevalence of Monoclonal Gammopathy of Undetermined Significance (MGUS), comparatively at younger age.

The outcome of this study would hopefully help in determine prevalence of monoclonal gammopathy of undetermined significance in our part of the country. Thus overall, this study would help to guide the management of patients with this common yet not well-understood disorder MGUS.

\section{Acknowledgements:-}

The authors are thankful to all faculties and staff of Department of Pathology, Darbhanga Medical College and Hospital, Laheriasarai, for their proper support during this study.

\section{Abbreviations:-}

LPD - Lymphoproliferative disorders, MG - Monoclonal gammopathy, MGUS - Monoclonal gammopathy of undetermined significance, MM -Multiple myeloma, NSPEP - Normal Serum Protein Electrophoresis, PG Polyclonal gammopathy, SMM - Smouldering multiple myeloma, SPEP - Serum Protein Electrophoresis, WMWaldenström's macroglobulinemia.

\section{References:-}

1. Alper, C.A., Plasma Protein Measurements as a Diagnostic Aid, N. Eng J Med, 291: 287-290, (1974).

2. Ritzmann, S.E. and Daniels, J.C., Diagnostic Proteinology: Separation and Characterization of Proteins, Qualitative and Quantitative Assays in Laboratory Medicine, Harper and Row, Inc., Hagerstown, (1979).

3. Tietz, N.W., ed., Textbook of Clinical Chemistry, W.B. Saunders Co., Philadelphia, pg. 579-582 (1986).

4. Hoffman R, et al., eds. Haematology: basic principles and practice. 3d ed. New York: Churchill Livingstone, 2000:369-70, 1403, 2505-9.

5. Ravel R. Clinical laboratory medicine: clinical application of laboratory data. 6th ed. St. Louis: Mosby, 1995:3436,350 .

6. Jacoby RF, Cole CE. Molecular diagnostic methods in cancer genetics. In: Abeloff MD, et al., eds. Clinical oncology. 2d ed. New York: Churchill Livingstone, 2000:119-21

7. Kyle RA. The monoclonal gammopathies. Clin Chem. 1994; 40(11 pt 2):2154-61.

8. Theodore X. O'Connell, Timothy J. Horita and Barsam Kasravi. Understanding and interpreting Serum protein electrophoresis, Am Fam Physician. 2005Jan1;71(1):105-112

9. International Myeloma Working Group (2003) Criteria for the classification of monoclonal gammopathies, multiple myeloma and related disorders: a report of the International Myeloma Working Group. British Journal of Haematology, 121, 749-757. 
10. Rajkumar SV, et al. International Myeloma Working Group ( IMWG) Updated Criteria for the Diagnosis of Multi ple Myeloma1 and NCCN Recommended Baseline Diagnosti c Workup Lancet Oncol. 2014;15(12):e538-548

11. Palumbo A, et al. J Clin Oncol. 2015 Aug 3. pii: JCO.2015.61.2267.International Myeloma Working Group (2015) Criteria

12. Kyle, R.A. (1978) Monoclonal gammopathy of uncertain significance; natural history in 241 cases. Mayo Clinic Proceedings, 50, 29-40.

13. Weiss, B.M., Abadie, J., Verma, P., Howard, R.S. \& Kuehl, W.M. (2009) A monoclonal gammopathy precedes multiple myeloma in most patients. Blood, 113, 5418-5422.

14. Landgren, O et al. (2009a) Monoclonal gammopathy of undetermined significance (MGUS) consistently precedes multiple myeloma: a prospective study. Blood, 113, 5412-5417.

15. Axelsson, U., Bachmann, R. \& Hällén, J. (1966) Frequency of pathological proteins (M-components) in 6,995 sera from an adult population. Acta Medica Scandinavica, 179, 235-247.

16. Fine, J.M., Lambin, P. \& Leroux, P. (1972) Frequency of monoclonal gammopathy ('M-components') in 13400 sera from blood donors. Vox Sanguinis, 23, 336-343.

17. Saleun, J.P., Vicariot, M., Deroff, P. \& Morin, J.F. (1982) Monoclonal gammopathies in the adult population of Finistère, France. Journal of Clinical Pathology, 35, 63-68.

18. Kyle, R.A. \& Rajkumar, S.V. (2006) Monoclonal gammopathy of undetermined significance. British Journal of Haematology, 134, 573-589

19. Vachon, C.M. et al (2009) Increased risk of monoclonal gammopathy of undetermined significance. Blood, 114, 785790.

20. Chng WJ, Glebov O, Bergsagel PL, and Kuehl WM (2007) Genetic events in the pathogenesis of multiple myeloma. Best Pract Res Clin Haematol 20(4):571-596.

21. Singh, J., Dudley, Jr, A.W. \& Kulig, K.A. (1990) Increased incidence of monoclonal gammopathy of undetermined significance in blacks and its age-related differences with whites on the basis of a study of 397 men and one woman in a hospital setting. Journal of Laboratory and Clinical Medicine, 116, 785-789.

22. Cohen, H.J. (2006) Prevalence of monoclonal gammopathy of undetermined significance. New England Journal of Medicine, 354, author reply 2832.

23. Landgren, O et al (2006) Risk of monoclonal gammopathy of undetermined significance and subsequent multiple myeloma among African American and white veterans in the United States. Blood, 107, 904-906.

24. Kyle RA, Therneau TM, Rajkumar SV, Offord JR, Larson DR, Plevak MF, et al. A long-term study of prognosis in monoclonal gammopathy of undetermined significance. N Engl J Med. 2002; 346:564-9.

25. Tietz Fundamentals of Clinical Chemistry, Carl A. Burtis, Edward R. Ashwood, MD, pages 3-4, Fifth Edition, (1996).

26. Landgren $\mathrm{O}$ et al, Prevalence of Monoclonal gammopathy of undetermined significance among men in Ghana, Mayo Clin Proc. 2007 Dec; 82 (12): 1468-73.

27. Malacrida, V., De Francesco, D., Banfi, G., Porta, F.A. \& Riches, P.G. (1987) Laboratory investigation of monoclonal gammopathy during 10 years of screening in a general hospital. Journal of Clinical Pathology, 40, 793797.

28. Vladutiu, A.O. (1987) Prevalence of M-proteins in serum of hospitalised patients: physicians' response to finding Mproteins in serum protein electrophoresis. Annals of Clinical Laboratory Sciences, 17, 157-161.

29. Crawford, J., Eye, M.K. \& Cohen, H.J. (1987) Evaluation of monoclonal gammopathies in the 'well' elderly. American Journal of Medicine, 82, 39-45

30. Rajkumar, S.V., Lacy, M.Q. \& Kyle, R.A. (2007) Monoclonal gammopathy of undetermined significance and smoldering multiple myeloma. Blood Reviews, 21, 255-265.

31. Kyle, R.A. et al (2006) Prevalence of monoclonal gammopathy of undetermined significance. New England Journal of Medicine, 354, 1362-1369.

32. Anagnostopoulos A et al Incidence and evolution of monoclonal gammopathy of undetermined significance (MGUS) in Greece, An hematol.2002 Jul;81(7):357-61.

33. Iwanaga, M et al (2007b) Relationship between monoclonal gammopathy of undetermined significance and radiation exposure in Nagasaki atomic bomb survivors. Blood, 113, 1639-1650.

34. Jenny Bird et al, UK Myeloma Forum ( UKMF) and Nordic Myeloma Study Group (NMSG ): guidelines for the investigation of newly detected M-proteins and the management of monoclonal gammopathy of undetermined significance ( MGUS), British Journal of Hematology, 147, 22-42, 2009, Blackwell Publishing Ltd.

35. James R. Berenson et al, Monoclonal gammopathy of undetermined significance: a consensus statement British Journal of Hematology, 150, 28-48, 2010, Blackwell Publishing Ltd. 